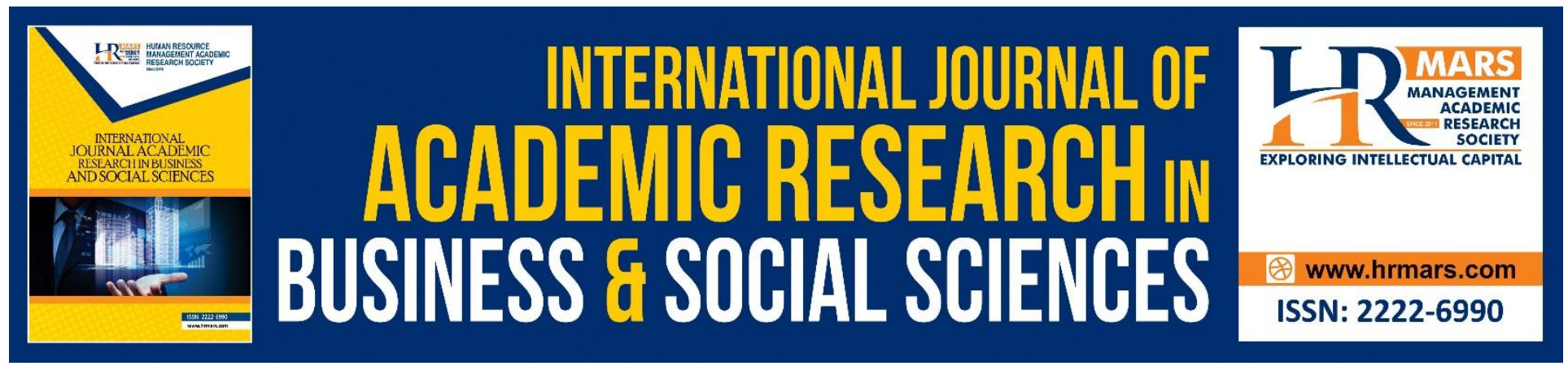

\title{
Minor's Capacity to Contract in Malaysia: Issues and Challenges
}

Noraida Harun, Asiah Bidin, Kamaliah Salleh, Noor 'Ashikin Hamid

To Link this Article: http://dx.doi.org/10.6007/IJARBSS/v8-i12/5257

DOI: $10.6007 /$ IJARBSS/v8-i12/5257

Received: 18 Oct 2018, Revised: 17 Dec 2018, Accepted: 11 Jan 2019

Published Online: 14 Jan 2019

In-Text Citation: (Harun, Bidin, Salleh, \& Hamid, 2018)

To Cite this Article: Harun, N., Bidin, A., Salleh, K., \& Hamid, N. 'Ashikin. (2018). Minor's Capacity to Contract in Malaysia: Issues and Challenges. International Journal of Academic Research in Business and Social Sciences, 8(12), 1549-1556.

Copyright: @ 2018 The Author(s)

Published by Human Resource Management Academic Research Society (www.hrmars.com)

This article is published under the Creative Commons Attribution (CC BY 4.0) license. Anyone may reproduce, distribute, translate and create derivative works of this article (for both commercial and non-commercial purposes), subject to full attribution to the original publication and authors. The full terms of this license may be seen

at: http://creativecommons.org/licences/by/4.0/legalcode

Vol. 8, No. 12, 2018, Pg. 1549 - 1556

http://hrmars.com/index.php/pages/detail/IJARBSS

JOURNAL HOMEPAGE

Full Terms \& Conditions of access and use can be found at http://hrmars.com/index.php/pages/detail/publication-ethics 


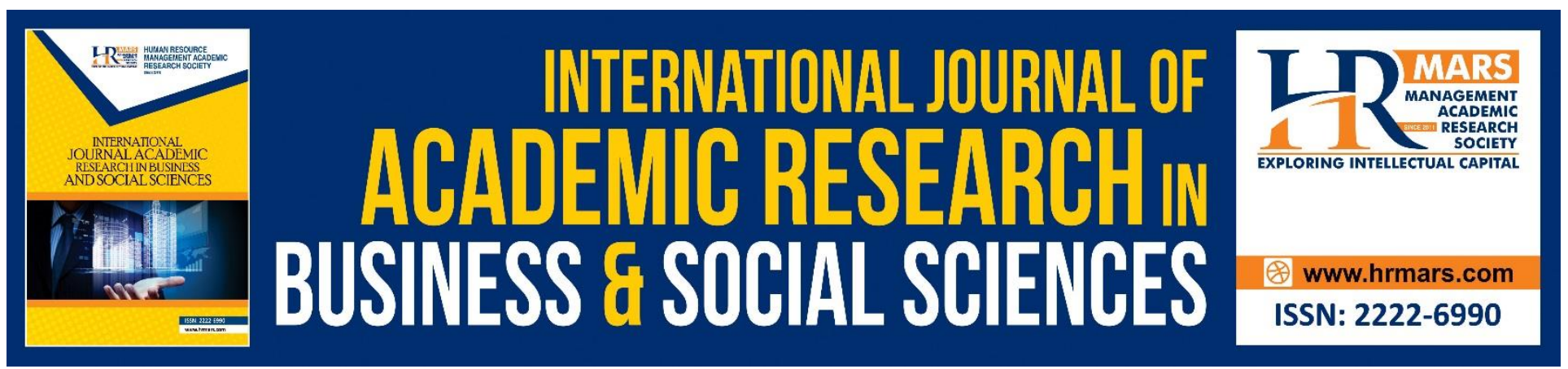

\title{
Minor's Capacity to Contract in Malaysia: Issues and Challenges
}

\author{
Noraida Harun
}

Universiti Sultan Zainal Abidin (UniSZA), Faculty of Law and International Relations, Gong Badak

Campus, 21300 Kuala Nerus, Terengganu, Malaysia

\section{Asiah Bidin}

Universiti Sultan Zainal Abidin (UniSZA), Faculty of Law and International Relations, Gong Badak Campus, 21300 Kuala Nerus, Terengganu, Malaysia

\section{Kamaliah Salleh}

Universiti Sultan Zainal Abidin (UniSZA), Faculty of Law and International Relations, Gong Badak Campus, 21300 Kuala Nerus, Terengganu, Malaysia

\section{Noor 'Ashikin Hamid}

Universiti Sultan Zainal Abidin (UniSZA), Faculty of Law and International Relations, Gong Badak Campus, 21300 Kuala Nerus, Terengganu, Malaysia

\begin{abstract}
Background: Generally, every person is competent to enter into a contract. The law, however, places limitations upon the capacity of certain persons to make a binding contract. These persons include minors. The Contracts Act 1950 does not stipulate the effect of an agreement entered into by a minor and from the decided cases show that all contracts entered into by a minor is void and a minor cannot sue or be sued under such contract. Objective: This article is aimed to discuss the effect of minor's contract in the case of minor's false representation of age and exceptions to the general rule on capacity to contract. Results: Everyone is capable of entering into a contract, but a minor is in need of legal protection because of their age incapable to appreciate their own actions. Conclusion: Some recommendations and solutions to improve the law in order to curb a problem rose in the minor's contract.
\end{abstract}




\section{INTRODUCTION}

According to Alsagoff (2010), every person who is competent to contract is free to contract upon such terms as he thinks fit. So long as the consideration and object of the agreement is lawful and not expressly declared to be void and he enters into the contract freely and voluntarily his contract shall be enforced by the courts of justice. The law however placed limitations upon the capacity of certain persons to bind themselves by a promise or to enforce a promise made to them. These person include minors, insane persons and bankrupts. Section 10 of the Contract Acts 1950 clearly states that all agreements are contracts if they are made by free consent of the parties competent to contract. Section 11 of the Contract Act provides a person is competent to contract when he is of the age of majority according to the law to which he is subject, and who is of sound mind, and is not disqualified from contracting by any law to which he is subject. A person who is below 18 years old is a minor in Malaysia as stated under section 2 of the Age of Majority Act 1971. In other words, one has attained the age of majority at the age of 18 . Thus only those of this age are legally competent to enter a valid contract.

\section{METHODOLOGY}

The study adopts a qualitative approach where data are collected through library research and contents analysis method. The study also analyses various texts such as journals, cases, statutes, reports and books.

\section{RESULTS}

Based on the article, although as a general rule, all contracts that entered into by a minor is considered void, but the law, however placed limitations upon the capacity of certain persons to enforce a promise made to them. The exceptions to this general rule that made the contract is still valid and enforceable are marriage contract, contract of employment and apprenticeship, contract for necessaries, scholarship agreement and contract for insurance. There are several issues and challenges in minor's contract, especially when it deals with a minor who has misrepresented his age, electronic contract, a contract of employment and contract for insurance. The recommendations and solutions are also highlighted in this paper in order to protect the interest of a minor.

\section{DISCUSSION}

\section{Effect of an Agreement Entered into by Minor}

The Contracts Act 1950 (CA 1950) does not provide for the effect of an agreement that have been made or entered into by a person who is not competent to contract. However, in the Indian case of Mohori Bibee v Dhurmodas Ghose (1903) ILR 30 Cal 536, the Privy Council held that the combined effect of section 9 and 10 of the Indian CA 1872 which is in pari materia to section 10 and 11 of the Malaysian CA 1950, rendered such contracts void because of lack of capacity. The contractual incapacity of a minor is regarded as a protection of the minor against the consequences of its own action and presumed lack of judgment in such matters. The decisions of Mohori Bibees's case is referred to and had been relied on in Malaysia in the case of Tan Hee Juan v Teh Boon Keat (1934) ML 96, the High Court, applying the decision of the Privy Council established earlier in the Mohori 
Bibee's case, agreed that contracts by minors are void. Essentially, this means that the eyes of the law, a minor cannot sue or be sued upon such void contract (Amin \& Mohd Nor,2011). Under English law, the law on contract by minors based itself on two principles. The first is the law must protect the minor against his experience which may enable an adult to take unfair advantage of him, or to induce him to enter into a contract which, though in itself fair, is simply improvident, secondly, the law should not cause unnecessary hardship to adults who deal fairly with minors. From this point, a contract entered into by minor is either valid or voidable in English law. If the subject-matter of the contract is necessaries, the contract is valid. If they are not necessaries, the law treats the contract as being voidable at the minor's option. Minor's contracts in England are voidable in two senses, first, contracts which bind the minor unless he repudiated them, second, contracts that does not bind a minor unless he ratifies them within reasonable time after attaining majority.

\section{Exceptions to the General Rule in Capacity to Contract}

Although a contract entered into by minor is void, nevertheless, there are five exceptions to this general rule when the contract is still valid and enforceable.

Firstly: Marriage contract by minor. In Malaysia, a minor can enter into a marriage contract and is bound with the contract. Promise of marriage entered into by minors or their parents on their behalf have been held to be valid. Section 4(a) of the Age of Majority Act 1971, now provides that nothing in this Act shall effect the capacity of any person to act in the following matters, namely marriage, divorce, dower and adoption. In the case of Rajeswary \& Anor v Balakrishnan \& Ors (1958) 3 MC 178, it was held that a contract to marry entered into by minors are distinguishable from other classes of contract and do not come within the principle laid down in Mohori Bibee's case. In this case, there was a breach of contract following the valid contract though the party was a minor. In Malaysia, Muslim marriage is governed by different Islamic Family Law Enactment of each state and the Islamic Family law ( Federal territory) Act 1984 (IFLA 1984) for the Federal Territories provides that a male must be of 18 years of age and the female must be of 16 years of age before a marriage can be solemnized. If a man a woman want to solemnize a marriage but they are below the minimum age, they must get the consent in writing from the Shariah judge ( section 8 IFLA). Thus, IFLA 1984 prohibits solemnization of early marriage for boys and girls.

For non-Muslims law in Malaysia, as stated in section 10 of the Law Reform (Marriage and Divorce) Act 1976, the minimum age for solemnizing a marriage for both male and female is at 18 years. However, a female who reached at the age of 16 years, can solemnize the marriage after obtaining authorization of a licence granted by the Chief Minister (section 21(2) of the Law Reform (Marriage and Divorce ) Act 1976 [Abdul Jalil,2010]. Although the minimum age for marriage for non-Muslim is 18 years, under section 12 of the Law Reform (Marriage and Divorce) Act 1976, a person below the age of 21 years is required, before marrying to obtain the consent in writing of his or her father. According to Rosli (2012), the contract is still valid eventhough the requirement under the Age of Majority Act 1971 is not complied with. The case of Rajeswary v Balakrishnan is, however, still relevant

Secondly: A contract of employment and apprenticeship. Minor's employment is regulated by the Children and Young Persons ( Employment) Act 1966 which provides any child or young person 
may enter into a contract of service and be employed. However, such person cannot be an employer. It defines child as person who has not completed his 14 years of age and Young person means any person who has not completed the age of 16. In other words, young person refers to any person between the age of 14 and 16. According to Fong (2010), this Act likely legitimizes child labour. At the same time, they are protected from being sued for damages and indemnity under section 13 of the Employment Act 1955.

Thirdly: Scholarship agreement. The defence of lack of capacity of minors to contract was raised in actions for breach of scholarship agreements. A significant case of Government of Malaysia $v$ Gurcharan Singh \& Ors [1971] 1 MLJ 211, the issue in this case was whether scholarship for a student who was a minor who attended practical training overseas amounted to contract for necessaries. The High Court held that the scholar agreement was void and unenforceable between the government and the minor. As a result of the above cases, the Contract (Amendment) Act 1976 was passed, section 4 (a) provides that no scholarship agreements' shall be invalidated on the ground that the scholar entering into such agreement is not of the age of majority. In other words, a scholarship agreement entered into by a minor is valid. So, if a minor has accepted the offer to pursue his studies, his agreement for scholarship is valid and enforceable. If a minor breaches the contract, he will be liable and is entitled to be sued under the contract (Rosli,2012).

Fourthly: Contract for insurance. Under the Insurance Act 1963, a minor above the age of 10 may enter into a contract of insurance but if he or she is under 16 years would require written parental consent to own an insurance policy. The Act allows a minor to enter into a valid agreement for contract of insurance. This exception is based on the presumption that it is in a minor's best interest to insure himself or his property against contingencies.

Fifthly: Contract for necessaries. Although all contracts entered into by minors are void, section 69 of the Contracts Act allows a person who was supplied necessaries to the minor to be reimbursed from the property of the minor. The word necessaries is not defined in the Contracts Act 1950 nor under the Sale of Goods (Malay State) Ordinance 1957. All that is said under section 69 of the Contracts Act is that what is supplied must be suited to the minor's condition in life and therefore the common law definition would be assistance. Necessaries have been statutorily defined in section 2 of the English Sale of Goods Act 1893 as meaning 'goods suitable to the condition in life of such an infant and to his actual requirement at the sale and delivery'. In Nash v Inman (1908) 2 KB 1, the tailor failed in his action because he had not established that the clothes were suitable to the condition in life of the minor and in this case, the student was already adequately supplied with clothes. Thus, whatever goods supplied to the minor must be supplied to his actual requirements and conditions of the life of the minor and the need at the time it was delivered. The Malaysian court had referred to its decision for guidance. In Government of Malaysia v Gurcharan Singh and Ors (1971) 1 ML 211, Chang Min Tat J said that: "In my view, the word necessaries must be construed broadly and in any decision involving whether what are supplied are or are not necessaries, it is incumbent to have regard to the facts of the case, the conditions and circumstances in which the supply was made and the purpose which is served." Like contract for necessary goods, a contract for delivery of necessary services to a minor will also be enforceable. 


\section{Misrepresentation of Age by Minor}

Where a minor has misrepresented his age and thereby induced a person to contract with him, the person cannot sue the minor on the contract. On the other hand, the minor still can plead minority to avoid the contract. In the case of Mohamed Syedol Ariffin v Yeoh Ooi Gark [1916] 2 AC 575, the Privy Council held that the misrepresentation was not fraudulent and even if it was, no action could been forced against the appellant as he was still a minor. In $R$ Natesan $v K$ Thanaletchumi (1952) ML 1 , the High Court also held that even if an infant had falsely misrepresented herself to be a major and had thereby induced a person to enter into a contract, she is not stopped from pleading such infancy to avoid the contract.

The English law however applied the law of restitution in the case where a minor misrepresented his age when he entered into a contract. Under the common law, if a minor misrepresented his age and received any money or benefits from the contract, he must restore it to the person whom he received it provided that it is still identifiable and within his possession (Rosli,2012). In the case of misrepresentation of age by a minor, it looks like to cause injustice to the major party who deals with the minor's contract. Although the intention of the law is to protect the interest of the minor, but it seems that the new generation now is different. It is not impossible that the minor who entered into the contract with the intention to fulfill their needs and interests. If the law still continues to give the opportunity to the minor to enter into the contract in the case of misrepresentation of age, then this will continue to give injustice to the major party who deals with him.

\section{Issues and Challenges in Minor's Capacity to Contract}

In a valid binding contract, all parties must be competent to enter into a contract. This principle regarding the capacity of the parties to contract applies also in the electronic contracts. Thus, a contract with a minor is void unless the contract falls under the exception as mentioned above. In an electronic contract, where the parties are not dealing with one another face to face, it will be difficult to determine the capacity of the parties. To overcome this situation, identity certification and statement regarding the capacity of a person to contract is important. The seller also should take opportunity to obtain specific information from the purchaser such as his name, address, age etc. In other words, the seller must take necessary steps and verify the age of the transacting parties to any transaction by requiring the customer who wants to purchase from the seller needs to acknowledge that the identity specified in the form is the actual customer identity and any misrepresentation of identity will subject to legal action ( Tasneem,2011,Mat Jusoh, Borhan \& Zakaria,2015).

In the case of misrepresentation of age is not covered by the Contracts Act. But this issue should be taken into account by the government as it may often lead to an injustice to a major party. Although section 11 of the Contracts Act provides who is competent to contract, but the Act fails to provide for the effect of the contract entered into by a minor. Obviously, the contract entered into by a minor by misrepresentation of age should be prevented through the provisions of the law in order to give protection to the aggrieved party. Besides that, the Fifth Indian Law Commission (13 ${ }^{\text {th }}$ Report, Contract Act 1872) provides that a minor who has received something by false misrepresentation of his age, he must restore the goods received. It can at least restore the status quo. This 
recommendation is in line with the principle of restitution provided under English law of contract which requires the minor to return the benefits received which are still in his possession ( Ahmad Yusoff, Mohamed Isa \& Abdul Aziz,2008).

According to the Employment Act 1855 and the Children and Young Person (Employment) Act 1966 provides that children below the age of 14 and young persons between the ages of 14 and 16 are competent to enter into a contract of employment but shall not become an employer. It is suggested that a young person between the ages of 14 is allowed to become an employer if they came from a poor family and needed their child to work to earn their lives.

In the case of a contract for insurance, as mentioned above, allows only persons who have attained the age of 10 years to own insurance policies and if the person is below the age of 16, the consent of a parent or guardian is required in writing before he can own a policy insurance. In other words, the insurance is effected between the age of 10 to 16. So it is suggested to remove the minimum age of capacity to enter into an insurance contract, provided the written consent from the policy owner's parent or guardian is obtained for minor, so the baby who just born should have the rights to have covered by insurance with the consent in writing of his or her parents or guardian.

\section{CONCLUSION}

For a contract to be valid, the essential ingredients of a contract must be present. The common requirements to be present in an enforceable contract are offer, acceptance, consideration and capacity. It assumed that everyone is capable of entering into a contract, but a minor is in need of legal protection because of their age incapable to appreciate their own actions. The technology does not change the necessities of these elements to form a valid contract, but one has to be careful when dealing with minor's contract because it can create a problem and challenges to a person who deals with them.

\section{Corresponding Author}

Noraida Harun, Universiti Sultan Zainal Abidin (UniSZA), Faculty of Law and International Relations, Gong Badak Campus, 21300 Kuala Nerus, Terengganu

Email: noraida@unisza.edu.my

\section{References}

Abdul Jalil, M. (2010), Islamic Law of Contract is getting Momentum. International Journal of Business and Social Science, 1(2), 175-186.

Ahmad Yusoff, S.S., Mohamed Isa, S., Abdul Aziz, A. (2009). Akta Kontrak 1950 (Akta 136): Keperluan Semakan Semula. In Abdul Rahim, A., Abdul Manap, N. \& Rajamanickam,R. (Eds.). Isu-isu Perundangan di Malaysia: Satu Anjakan Paradigma. (1-35). Selangor: Fakulti Undang-undang, Universiti Kebangsaan Malaysia. 
Alsagoff, S.A. (2010), Principles of the law of Contract in Malaysia. ( $3^{\text {rd }}$ ed). Singapore: Lexis Nexis Pte Ltd.

Amin, N., Mohd Nor, R. (2011). Issues on essential elements of formation of E-Contract in Malaysia: E-Consumers Perspective. Journal of Applied Sciences Research,7(13), 2219-2229.

Fong, C. M. (2010). Contract Law in Malaysia. Selangor : Sweet \& Maxwell Asia.

Mat Jusoh, A.J., Borhan, J.T.,Zakaria, M.B. (2015). Isu-isu Syariah dalam Pelaksanaan E-Dagang. Jurnal Islam dan Masyarakat Kontemporari.10. 68-80.

Rosli, R.A. (2012), Parties to the Contract. In Ishan Jan, M.N. (Eds). Law and Commerce the Malaysian Perspective. (pp 90-101). (2 ${ }^{\text {nd }}$ ed.). Selangor: IIUM Press.

Tasneem, F. (2011). The Legal Issues of Electronic Contracts in Australia. International Journal of Management and Business Research, 1(2), 85-92. 